\title{
Energy costs of protein and fatty acid synthesis
}

\section{By P. J. Reeds, K. W. J. Wahle and P. HagGaRty, Rowett Research Institute, Bucksburn, Aberdeen $A B 2{ }_{9} S B$}

The heat production of growing animals can be divided statistically into two components; one, a function of body-weight, the so-called maintenance heat production, the other a function of the rate of growth and of energy intake above that required for energy equilibrium. The second of these two components is presumably, at least in part, a consequence of the metabolic transformations which result in the deposition of body tissue (both lipid and protein) and is the subject of this paper.

The growth of an animal is the resultant of many separate but interconnected reaction sequences. We will concentrate upon two pathways, namely protein and fatty acid synthesis, and the contribution that these make to the energy expenditure of young growing animals. The 'nutritional' energy costs of these pathways of nutrient utilization can be calculated from their stoichiometry (Table I; Blaxter, 1969; Millward et al. 1976). The calculation involves consideration of at least three factors; ( $\mathrm{I}$ ) the energy cost of formation of the bonds in the macromolecule, (2) the energy cost of forming the monomers from which the final molecule is synthesized and (3) the cost of the synthesis of the ATP and reduced pyridine nucleotides which are required for the process of polymerization.

It should be noted that the energy cost so calculated is a minimal one. It will be higher if the rate of synthesis of the end-product exceeds the rate of accretion and if accelerated rates of protein and fat deposition also involve the activation of other energetically wasteful processes. The former of these two factors can be illustrated by a consideration of the energy cost of protein synthesis.

Nitrogen and energy balance, heat production and protein synthesis in the whole body have been measured simultaneously in growing pigs (Reeds et al. 1980, 1981). In these experiments the rate of growth was manipulated in three ways; (I)

Table I. The energetic efficiency of triacylglycerol synthesis from different substrates*

\begin{tabular}{|c|c|}
\hline & $\begin{array}{l}\text { Heat production } \\
(\mathrm{kJ} / \mathrm{mol} \text { synthesized }\end{array}$ \\
\hline Fatty acids $\rightarrow$ triacylglycerol $\dagger$ & 480 \\
\hline Carbohydrate $\rightarrow$ triacylglycerol & 6104 \\
\hline Amino acids $\rightarrow$ triacylglycerol $\neq$ & 12767 \\
\hline
\end{tabular}

*After McGilvery (1970) and Millward et al. (1976).

$\dagger$ Assuming it to be tripalmitylglycerol.

$\ddagger$ Assuming the division of animo acid metabolism between glucose and ketone body synthesis given by McGilvery (1970). 
by altering the amount of feed offered to the animal, (2) by altering the intake of non-protein energy (NPE) independently of protein and (3) by altering the intake of protein independently of NPE. The results (Table 2) demonstrate that the relationship between protein deposition and protein synthesis is not fixed. Using the 'theoretical' value for the energy cost of peptide-bond synthesis calculated by Buttery \& Boorman (1976) and by Millward et al. (1976) $(4.5 \mathrm{~kJ} / \mathrm{g}$ protein synthesized) the energy cost of the increased protein synthesis accompanying the increments in protein deposition ranges from 3.6 (fat supplement) to 21.5 (protein supplement) $\mathrm{kJ} / \mathrm{d}$ additional protein deposition. In young pigs the minimum calculated energy expenditure associated with body protein synthesis was between 16 and $26 \%$ of total heat production (Table 3 ).

It must be recognized that in drawing these conclusions we are assuming that protein synthesis is estimated accurately. There are reasons to suspect (Golden $\&$ Waterlow, 1977; Reeds \& Lobley, I980) that the method used in the experiments discussed above underestimates protein synthesis in the body.

Table 2. Changes in body protein synthesis and protein deposition (nitrogen $\times$ 6.25 ) in growing pigs receiving increased amounts of whole diet, non-protein energy (NPE) or protein

$\begin{array}{lcc} & \begin{array}{c}\text { Increase in } \\ \text { protein } \\ \text { deposition }(\mathrm{g} / \mathrm{d})\end{array} & \begin{array}{c}\text { Increase in } \\ \text { protein } \\ \text { synthesis* }(\mathrm{g} / \mathrm{d})\end{array} \\ \text { Dietary supplement } & +68 & +88 \\ \text { Whole diet } & +45 & +36 \\ \text { NPE as fat } & +4 \mathrm{I} & +64 \\ \text { NPE as carbohydrate } & +34 & +159\end{array}$

*Protein synthesis was calculated as the difference between the irreversible loss of leucine (leucine flux) and the rate of leucine oxidation assuming that body protein contains $67 \mathrm{~g}$ leucine $/ \mathrm{kg}$.

Table 3. Total daily heat production and the minimum contribution due to protein synthesis in pigs (28-36 kg body-weight)

\begin{tabular}{|c|c|c|}
\hline Diet & $\begin{array}{c}\text { Heat } \\
\text { production } \\
\left(\mathrm{kJ} / \mathrm{kg}^{0.75} \text { per } \mathrm{d}\right)\end{array}$ & $\begin{array}{l}\text { Minimum due to } \dagger \\
\text { protein synthesis } \\
\left(\mathrm{kJ} / \mathrm{kg}^{0.75} \text { per } \mathrm{d}\right)\end{array}$ \\
\hline \multicolumn{3}{|l|}{ Whole diet } \\
\hline I & 553 & 92 \\
\hline 2 & $75^{\circ}$ & 133 \\
\hline 3 & 810 & 162 \\
\hline High carbohydrate & 876 & 172 \\
\hline High fat & 856 & 169 \\
\hline High protein & 785 & 208 \\
\hline
\end{tabular}

"By open circuit indirect calorimetry ( 4 d measurement).

tProtein synthesis was calculated as the difference between the irreversible loss of leucine (leucine flux) and the rate of leucine oxidation assuming that body protein contains $67 \mathrm{~g}$ leucine $/ \mathrm{kg}$ and assuming the expenditure of $4.5 \mathrm{~kJ} / \mathrm{g}$ synthesized. 
Recently, measurements of body protein synthesis have been made in immature Zucker rats in which the method adopted (a modification of that described by Garlick et al. 1980) minimizes the inaccuracy. In these experiments daily heat production was not estimated directly but was calculated from the difference between energy gain in the body and energy intake. The results (Table 4 ) suggest that in both 18 and 25 -d-old lean Zucker rats offered feed ad lib. the energy required for protein synthesis contributes a minimum of $17 \%$ of daily energy expenditure. These results all indicate that the energy required for whole-body protein synthesis makes a minor but nevertheless significant contribution to heat production and that, as intake increases, it may make an increasing contribution to the total.

The energetic efficiency of fat deposition includes at least three factors; the energy cost of 2-carbon incorporation ( $80 \mathrm{~kJ} / \mathrm{mol} \mathrm{2-C} \mathrm{incorporated),} \mathrm{changes} \mathrm{in} \mathrm{the}$ recycling of fatty acids (which seem to be a minor contributor; Baldwin et al. I980; Newsholme, 1982) and the costs of the metabolism of the substrates which supply the carbon for triacylglycerol (Table $\mathbf{r}$ ).

The total rate of fatty acid synthesis can be determined from the incorporation of ${ }^{3} \mathrm{H}$ from ${ }^{3} \mathrm{H}_{2} \mathrm{O}$ (Windmueller \& Spaeth, 1966) and we have been making such measurements in immature $(25$-d-old) lean and obese Zucker rats. The results suggest, that in the body as a whole, the rate of fatty acid synthesis is similar to the rate of fat deposition ( 0.23 and I.I $\mathrm{g} / \mathrm{d}$ in lean and fat rats respectively) and that the process of fatty acid synthesis itself contributes approximately $\mathrm{I}$ and $4 \%$ of total daily heat production in the lean rats and in fat rats respectively (Table 5).

Concurrent experiments in which the incorporation into fat of $\left[{ }^{14} \mathrm{C}\right.$ - $] g l u c o s e$, administered via the stomach, has been measured, suggest that glucose-C contributes about $30 \%$ of the fatty acid $\mathrm{C}$ in lean rats and $45 \%$ in obese animals. Accordingly fatty acid synthesis from glucose will contribute $\mathrm{I}$ and $6 \%$ of total daily energy expenditure in lean and fat animals respectively. The source of the remaining $\mathrm{C}$ can only be a matter for speculation but it seems to us that $\mathrm{C}$ derived from the catabolism of amino acids may be a major contributor. Typically, when offered a stock 'rodent' diet ad lib. the lean rats deposit as protein some $50 \%$ of the protein that they ingest and the remainder is presumably either oxidized

\section{Table 4. Daily heat production and whole body protein synthesis in lean Zucker rats at two ages}

\begin{tabular}{|c|c|c|c|}
\hline $\begin{array}{l}\text { Age post } \\
\text { partum }\end{array}$ & $\begin{array}{c}\text { Daily heat } \\
\text { production } \\
\left(\mathrm{kJ} / \mathrm{kg}^{0 \cdot 75} \text { per } \mathrm{d}\right)\end{array}$ & $\begin{array}{c}\text { Daily protein } \\
\text { synthesist } \\
\text { (g protein } / \mathrm{kg}^{0-75} \\
\text { per d) }\end{array}$ & $\begin{array}{l}\text { Heat production } \\
\text { due to } \\
\text { protein synthesis } \\
\left(\mathrm{kJ} / \mathrm{kg}^{0 \cdot 75} \text { per } \mathrm{d}\right)\end{array}$ \\
\hline I 8 & 554 & $20 \cdot 6$ & 93 \\
\hline 25 & 635 & $26 \cdot 9$ & 121 \\
\hline
\end{tabular}

* Measured from the difference between daily energy intake (using the data of Godbole et al. I 98 I for I 8-d-old animals) and daily energy gain (by comparative slaughter).

$\dagger$ Measured by the Method of Garlick et al. (Ig80). 
Table 5. Preliminary observations on the contribution of fatty acid synthesis to daily heat production in lean and fat male Zucker rats of $25 d$ of age

\begin{tabular}{|c|c|c|c|}
\hline \multirow[b]{2}{*}{ Phenotype } & \multirow[b]{2}{*}{$\begin{array}{l}\text { Daily heat } \\
\text { production } \\
(\mathrm{kJ} / \mathrm{d})\end{array}$} & \multicolumn{2}{|c|}{ Heat production $(\mathrm{kJ})$ due to: } \\
\hline & & $\begin{array}{l}\text { Fatty acid } \\
\text { synthesis* }\end{array}$ & $\begin{array}{c}\text { Glucose } \\
\text { incorporation } \\
\text { into fatty acid }\end{array}$ \\
\hline Lean & 72 & 0.59 & 0.57 \\
\hline Fat & & $2 \cdot 84$ & $4 \cdot 06$ \\
\hline
\end{tabular}

completely or incorporated into body fat. If the latter is the case then the energetic efficiency of fat deposition will be lower than that calculated on the basis of carbohydrate as the predominant source of fatty acid C.

In summary, it appears that protein synthesis accounts for a minimum of $20 \%$ of total daily heat production in immature growing animals. Above maintenance, this process accounts for a somewhat higher proportion (25\%). In immature lean rats fatty acid synthesis occurs at the same rate as fat deposition and accounts for $1 \%$ of total heat production ( $3 \%$ of heat production above maintenance). The remainder of the inevitable metabolic cost of fatty acid synthesis depends upon the substrates which supply C. Preliminary results suggest that a comparatively low proportion of fatty-acid $\mathrm{C}$ is derived immediately from dietary carbohydrate and the synthesis of fatty acids from this source contributes a further $3 \%$ of heat production above maintenance. If protein supplies the $\mathrm{C}$ for the remainder of fatty acid synthesis a further $20 \%$ of heat production above maintenance can be accounted for. Thus approximately $50 \%$ of heat production above that required to maintain the animal in energy balance, can be accounted for by the necessary metabolic accompaniments of the deposition of body fat and body protein.

\section{REFERENCES}

Baldwin, R. L., Smith, N. E., Taylor, J. \& Sharp, M. (1980). F. Anim. Sci. 51, I4 Ib.

Blaxter, K. L. ( 1969$)$. The Energy Metabolism of Ruminants, 3 rd ed. London: Hutchinson.

Buttery, P. J. \& Boorman, K. N. (1976). In Protein Metabolism and Nutrition, p. 197 [D. J. A. Cole, K. N. Boorman, P. J. Buttery, R. J. Neale and H. Swan, editors]. London: Butterworths.

Garlick, P. J., McNurlan, M. A. \& Preedy, V. R. (1980). Biochem. F. 192, 719.

Godbole, V. J., Grundleger, M. L., Pasquine, T. A. \& Thenen, S. W. (1981). F. Nutr. 111 1, 480.

Golden, M. H. N. \& Waterlow, J. C. (1 977). Clin. Sci. Mol. Med. 53, 277.

McGilvery, R. W. (1970). Biochemistry, a Functional Approach. Philadelphia and London: W. B. Saunders.

Millward, D. J., Garlick, P. J. \& Reeds, P. J. (1976). Proc. Nutr. Soc. 35, 339.

Newsholme, E. A. (1982). Proc. Nutr. Soc. 4I, I83.

Reeds, P. J., Cadenhead, A., Fuller, M. F., Lobley, G. E. \& McDonald, J. D. (I980), Br. F. Nutr. 43,455 .

Reeds, P. J., Fuller, M. F., Cadenhead, A., Lobley, G. E. \& McDonald, J. D. (1981). Br. F. Nutr. 45,539 .

Reeds, P. J. \& Lobley, G. E. (1980). Proc. Nutr. Soc. 39, 43. 
Waterlow, J. C., Garlick, P. J. \& Millward, D. J. (1978). Protein Turnover in Mammalian Tissues and in the Whole Body. Amsterdam: North Holland.

Webster, A. J. F. (1981). Proc. Nutr. Soc. 40, 129.

Windmueller, H. G. \& Spaeth, A. E. (1966). F. biol. Chem.24 r, $289 \mathrm{I}$. 